\title{
Is the soil seed bank a reliable source for passive restoration of bush-cleared semi-arid rangelands of South Africa?
}

\author{
Mthunzi Mndela ${ }^{1,2^{*}}$, Casper Ignacio Madakadze ${ }^{1}$, Florence Nherera-Chokuda ${ }^{2}$ and Sikhalazo Dube ${ }^{3}$
}

\begin{abstract}
Background: Bush clearing of encroached rangelands is crucial for restoration of herbaceous cover and diversity. Regeneration after bush clearing depends largely on the soil seed bank (SSB) size and composition. To assess the potential of the SSB to facilitate post-clearing herbaceous restoration, we examined the SSB density, composition and diversity and similarity between SSB and aboveground vegetation (AGV).

Methods: The study was conducted in semi-arid rangelands of Maseding and Kgomokgomo in North-West Province of South Africa. In each rangeland, all woody plants in three $1250 \mathrm{~m}^{2}$ plots were cut using saws and loppers, with the stumps treated with picloram. Paired observations were conducted in cleared and uncleared microsites. Soil samples were collected at three depths $(0-10,10-20$ and 20-30 cm) in each microsite in April (pretreatment), August, October and December 2016 and in April and August 2017. SSB was assessed using seedling emergence method, whereas pre- and post-clearing surveys of AGV were conducted in February 2016 and 2017, respectively.
\end{abstract}

Results: Cleared microsites had significantly $(p<0.01)$ higher seed bank densities (1872 and 693 seeds $\mathrm{m}^{-2}$ at Maseding and Kgomokgomo, respectively) relative to uncleared microsites in August 2017, with grasses accounting for higher densities than other plant functional groups in the upper $0-10 \mathrm{~cm}$. Pioneer grasses (Aristida congesta subsp. barbicollis, Brachiaria eruciformis and Tragus berteronianus) and invasive forbs (Bidens pilosa and Schkuhria pinnata) dominated the SSB in cleared microsites at Maseding, whereas succulents (Portulaca spp.) and pioneer grasses (T. berteronianus and Urochloa mosambicensis) were abundant at Kgomokgomo in August 2017. SSB and AGV were dissimilar until December 2016; thereafter, similarity increased significantly $(p<0.05)$ in cleared microsites (Sørensen's coefficient $=0.60$ to 0.66 at Maseding and 0.43 to 0.52 at Kgomokgomo) compared to uncleared microsites. Species diversity was highest in August 2016 and April 2017 at Maseding, but it did not differ between two microsites $(p>0.05)$. At Kgomokgomo, SSB was more diverse in cleared than uncleared microsites in April and August 2017.

Conclusion: High seed bank densities in the upper soil layer in cleared microsites would promote passive restoration, but regeneration is likely to be initiated by early successional species. However, close monitoring and eradication of invasive forbs and succulents is necessary following bush clearing. The tendency of SSB resembling AGV over time in cleared microsites signifies that seed production from AGV is important for passive restoration following bush clearing.

Keywords: Bush clearing, Seed bank density, Seed bank diversity, Sørensen's coefficient

\footnotetext{
* Correspondence: mthunzimndela@yahoo.com

${ }^{1}$ University of Pretoria, P/Bag X20, Hatfield, Pretoria 0028, South Africa

${ }^{2}$ Agricultural Research Council, API, P/Bag X02, Irene, Pretoria 0062, South

Africa

Full list of author information is available at the end of the article
} 


\section{Introduction}

Bush clearing is a commonly applied management tool to reduce woody plant canopy and densities in heavily encroached rangelands for restoration of grass cover, diversity and ground water recharge (Archer and Predick 2014). Bush clearing creates a window for recruitment by altering habitat conditions including increase in light, soil moisture and nutrient availability (Dodson et al. 2008). The reduction in tree-grass competition through bush clearing may increase the abundance, richness and production of herbaceous species. However, the effects of bush clearing on passive restoration are determined by the method of bush clearing, as different mechanical methods disturb the soil to varying degrees (Faist et al. 2015). The use of manual bush cutters followed by chemical stump treatment is less destructive to soil (Frank et al. 2018) and is mostly applied in South African rangelands by a national programme called Working for Water (WfW) which was launched in 1995 (Grossman and Holden 2007; Stafford et al. 2016). However, in South Africa, post-clearing monitoring of passive recovery of vegetation is rarely conducted on the assumption that plants will regenerate effectively from soil stored propagules (Fourie 2007). This highlights a need to assess the size, composition and regeneration capacity of the soil seed bank. Most importantly, soil seed bank not only indicates the past vegetation composition but also potential future communities and acts as a reservoir for conservation and restoration of plant species diversity (Bakker et al. 1996). Passive restoration is also influenced by post-clearing seed production of aboveground vegetation, seed dispersal from nearby areas and the ratio of desirable grasses to invasive species (Miao et al. 2016). Assessment of passive restoration based only on the aboveground vegetation tends to disregard the role that soil seed bank plays on ecosystem resistance and resilience (Dreber et al. 2011). Knowledge of the soil seed bank dynamics is important for understanding historical land use management and further provides insights on management strategies to be applied for future restoration (Cox and Allen 2008; Jonason et al. 2014).

Ample evidence shows that passive restoration is a function of the soil seed bank of annual forbs and grasses following bush clearing (Korb et al. 2005; Mndela et al. 2019; Siebert and Drebber, 2019). This is due mainly to the fact that early successional species produce large number of seeds which are highly persistent (Gelviz-Gelvez et al. 2016), and they colonise vigorously in bare patches once light availability increases in bushcleared sites (Mndela et al. 2019). As a result, soil seed bank and aboveground vegetation are tightly coupled, having a strong positive feedback especially during early successional stages (Bossuyt and Hermy 2004). However, the coupling between below and aboveground vegetation components may diminish with time due to a decline in abundance of annual species on the vegetation (Siebert and Drebber, 2019) and senescence of their seed bank (Bossuyt and Hermy 2004). Hence, monitoring the interrelationship between seed bank and vegetation is fundamental in assessing inflow of invasive species (Vieira et al. 2015) and feedbacks between below and aboveground vegetation components. The primary step is to assess the density and composition of the soil seed bank (Sakai et al. 2005; Lemenih and Teketay 2006) and timely track the species-specific seed persistence.

Persistence of the soil seed bank may vary widely depending on the germination requirements and plantrelated seed characteristics. For example, some species may germinate soon after seed set while dormancy release for other species requires extended exposure to germination cues (Baskin and Baskin 2014). Long-term persistence of seeds in the soil is an important strategy to avoid sporadic events aboveground (Esmailzadeh et al. 2011), and those seeds contribute substantially to post-disturbance regeneration (Lang 2006). Due to the differences in timing of dormancy release among species, it becomes crucial to conduct time-series assessments of the seed bank. Time-series assessments can provide valuable information about specific times at which species-specific maximum germination is achieved, which could possibly guide opportunistic management to deplete seed banks of problematic species. Various methods for assessment of seed bank have been developed including direct seed extraction and identification methods (e.g. floating and sieving) and indirect seed identification methods that rely on germination assays (Abella et al. 2013). In some studies, these two methods provided the same results (Price et al. 2010), whereas in others, they did not (Baskin and Baskin 2014). Both methods have advantages and flaws, with direct seed extraction and identification methods being capable of estimating more seeds than germination assays (Abella et al. 2013). However, direct seed extraction and identification methods may capture non-viable seeds (Tessema et al. 2016) and omit small-sized seeds, leading to both over- and underestimation of seed densities (Farnsworth et al. 2012). On the other hand, germination assays have high capacity to discriminate non-viable seeds from viable ones (Mndela et al. 2019) and can provide good results if the germination cycle is long enough and field conditions are correctly mimicked to allow germination of all seeds including dormant ones (Abella et al. 2013). The objective of this study was to evaluate time-series dynamics of the soil seed bank size, diversity and composition and relationship between soil seed bank and aboveground vegetation following bush clearing. Specifically, we aimed to answer two questions: (1) Do bushcleared and uncleared rangelands contain legacy seed 
banks that can be used for passive restoration and (2) can the similarities between soil seed bank and aboveground vegetation composition be relied on to inform future restoration applications in bush-cleared areas?

\section{Materials and methods}

\section{Description of the study areas}

The study was conducted at Maseding and Kgomokgomo communal rangelands of Makapanstad in Bojana District Municipality, North-West Province of South Africa. The altitude of the rangelands ranges from 900 to $1200 \mathrm{~m}$ above sea level (Mucina et al. 2006). The average annual rainfall is $459 \mathrm{~mm} \mathrm{year}^{-1}$ (Moerane 2013). The maximum monthly average temperatures range from $27-34{ }^{\circ} \mathrm{C}$ in summer and $20-23^{\circ} \mathrm{C}$ in winter. The respective minimum temperatures are $15-16^{\circ} \mathrm{C}$ and $3-$ $6{ }^{\circ} \mathrm{C}$ (DIGES 2012). The topography is gentle to slightly undulating (Mucina et al. 2006). These communal rangelands have different soil types, with Maseding having black vertic clays while Kgomokgomo is located on redyellow apedal sandy soils. The black vertic clays have a loose structure, high calcium carbonate content, exchangeable cations and poor drainage with high shrinking and cracking potential during wet and dry conditions (Fey 2010). Although soils are different between these two rangelands, they are very close to each other approximately $1.5 \mathrm{~km}$ apart and they experience similar climatic conditions. Maseding rangeland covers $14.5 \mathrm{~km}^{2}$ and Kgomokgomo rangeland covers $30.6 \mathrm{~km}^{2}$. The black vertic clays and red-yellow apedal soils are the main soil types in Springbokvlakte thornveld of the Central Mixed Bushveld bioregion (Mucina et al. 2006). Maseding and Kgomokgomo were selected as representatives of a large veld type. The woody vegetation structure and composition were different between these rangelands, with Maseding and Kgomokgomo consisting of 6 and 14 woody species, respectively. Vachellia tortilis (Willd.) Hayne and Vachellia tenuispina (I. Verd.) Kyal \& Boatwr were the most dominant woody species, and Eragrostis lehmanniana Nees, Aristida congesta subsp. barbicollis Roen. \& Schult and Corbichonia decumbens (Forssk.) Exell were the most dominant herbaceous species at Maseding. At Kgomokgomo, woody vegetation was dominated by Dichrostachys cinerea (L.) Wight \& Arn and $V$. tortilis, whereas Eragrostis pseudosclerantha Chiov, Cynodon dactylon (L.) Pers, Portulaca pilosa L. and Blepharis integrifolia (L.f.) E. Mey ex Schinz were the dominant herbaceous species. The total woody plant density was 3053 and 4851 trees $\mathrm{ha}^{-1}$ at Maseding and Kgomokgomo, respectively. The main encroaching woody plants were $V$. tortilis (2028 trees $\mathrm{ha}^{-1}$ ) at Maseding and D. cinerea (2701 trees $\mathrm{ha}^{-1}$ ) at Kgomokgomo. These rangelands are continuously grazed throughout the year. However, for the purpose of this study, the experimental plots were fenced to prohibit grazing until the end of sampling.

\section{Experimental layout and vegetation assessment}

In February 2016, three 2500- $\mathrm{m}^{2}$ bush-encroached blocks were randomly selected in each rangeland. Sites with similar woody vegetation structure, soil type and topography were selected, and the coordinates were recorded to peg the blocks. Eight $5 \times 5 \mathrm{~m}$ plots were marked in each block, with a line of four plots marked parallel to the other four plots. The plots in each line were interspaced by $5 \mathrm{~m}$, and the two parallel lines of plots were $20 \mathrm{~m}$ apart (Additional file 1: Fig. S1). Woody plants were identified in the plots. Three $1.7 \mathrm{~m}^{2}$ quadrats were placed in each plot, one at the centre and two at opposite corners to give 72 quadrats per rangeland. All herbaceous plants were identified to species level in each quadrat. In April 2016, all blocks were divided into two microsites (bush-cleared and uncleared) of $1250 \mathrm{~m}^{2}$. In the cleared microsites, woody plants were mechanically cleared using saws and loppers and the stumps were treated with picloram. The cut woody material was removed from cleared microsites. Four $25 \mathrm{~m}^{2}$ plots were marked in each microsite replicate, and plants were identified in the quadrats placed in the plots in the similar fashion as before bush clearing. The resprouts were sprayed with picloram during the rainy season. For both stump treatment and resprout control, picloram was applied at a recommended rate of $1 \%$ which has a minimal effect on non-target plants and soils (Smit 2005).

\section{Soil sampling and preparation for seed bank analysis}

Pre-treatment sampling was conducted in April 2016 using a soil auger with a $6-\mathrm{cm}$ diameter. Soil samples were randomly collected at three depths $(0-10,10-20$ and $20-30 \mathrm{~cm}$ ) along two parallel $50 \mathrm{~m}$ line transects per block, giving 288 samples ( 2 rangelands $\times 3$ blocks $\times$ 2 transects $\times 8$ random points $\times 3$ depths). After bush clearing, two fixed 50-m line transects were marked 15 $\mathrm{m}$ apart in each microsite replicate. Thereafter, soil samples were collected randomly at the same depths as before bush clearing. Post-clearing sampling was conducted in August, October and December 2016 and in April and August 2017. Soil samples were air-dried, sieved and preserved at $5{ }^{\circ} \mathrm{C}$ before transportation to the glasshouse for germination.

\section{Glasshouse germination}

Germination was conducted in the glasshouse at the University of Pretoria at constant temperatures of $25^{\circ} \mathrm{C}$ during the day and $10^{\circ} \mathrm{C}$ at night. The soil samples were bulked for each depth per block per microsite type (cleared and uncleared microsites). Each bulked soil composite was distributed evenly in 3 trays of $20 \times 30$ 
cm to give 108 trays ( 3 bulked samples $\times 3$ depths $\times 2$ microsites $\times 3$ blocks $\times 2$ rangelands). The soil layer in the trays was $3 \mathrm{~cm}$.

The germination trays were labelled and distributed randomly on benches and watered to field capacity twice a day (in the morning and afternoon). Germinated seedlings were counted, identified, and removed from the trays every second day of germination. The seedlings were identified to species level and functional groups (forbs, grasses, sedges, succulents, and woody plants). The unidentifiable seedlings were marked and identified at least a week later.

When no germination was observed for 4 consecutive days, soils were left to dry for 2 days, after which the trays were flipped over and watered continuously, twice a day to allow seeds that were originally at the bottom to germinate. The seedling emergence was monitored for 3 to 4 months for each sampling period to give hardcoated seeds enough time to germinate. Plant identification guidelines by van Oudtshoorn (2004) for grasses, Smith et al. (2017) for succulents, and van der Walt (2009) for forbs, sedges, and legumes were employed. The SSB species were categorised into decreaser, increaser I, increaser II, and invaders. Decreaser species are defined as those species that dominate in wellmanaged or moderately grazed rangelands. Increaser I species are the herbaceous species that dominate a rangeland that was under-grazed as a result of low stocking rate of grazers, whereas increaser II are the species that dominate the rangeland that was overgrazed (Tainton 1999). In this study, however, the category (increaser II) was not restricted to overgrazing only but to all types of anthropogenic disturbances including mechanical disturbance of soils. The species classified as invaders are those that colonise habitats out of their natural range, mostly the exotic species. The seedling density was extrapolated to $1 \mathrm{~m}^{2}$ based on the surface sampling area of the soil cores. Species abundance was calculated as the proportion of each species divided by the total number of all species in each treatment multiplied by $100 \%$.

\section{Statistical analysis}

Seed bank diversity was calculated using Shannon diversity index according to Magurran (2004) as follows:

$$
H=-\sum_{i=1}^{S} P_{i} \ln P_{i}
$$

where $H=$ Shannon diversity index, $S=$ number of species in each microsite replicate, and $P_{i}=$ relative abundance of species $i$.
The relationship between SSB and AGV was assessed using Sørensen's similarity index. The index was calculated according to Chao et al. (2006) as follows:

$$
\text { Sørensen's index }=\frac{2 \mathrm{C}}{2 \mathrm{C}+\mathrm{A}+\mathrm{B}}
$$

where $C$ is the number of species shared between SSB and AGV in each microsite replicate, and $A$ and $B$ are the total numbers of species per microsite replicate in AGV and SSB, respectively. For determination of the similarity between SSB and AGV from April to October 2016, we used pre-treatment total number of species $(B)$ for AGV because the dry season extends to October in the study areas. No plants would have germinated even if there were new seeds dispersed into experimental plots.

Normality and homoscedasticity of the response variables (SSB densities, richness, diversity, and Sørensen's coefficients) were assessed using Shapiro-Wilk and Levene's tests before analysis. Seed densities and Sørensen's coefficients were transformed using $\log _{10}(x+1)$ and arcsine $(x$ $+0.5)$, respectively. Repeated measures analysis of variance (RMANOVA) was conducted, with sampling repeated 5 times after bush clearing. The main effects of microsites $(n=2)$, burial depth $(n=3)$, sampling periods, and their interactions were assessed using general linear models of SAS version 9.4, Inc., Cary, NC, USA (SAS Institute 2009). Pre-treatment densities were added as covariates in the analysis. A $t$ test was used to conduct pairwise mean comparisons at $95 \%$ confidence level.

\section{Results}

\section{Total seed bank densities in cleared and uncleared microsites}

At Maseding, bush clearing $(p<0.05)$ and time since bush clearing $(p<0.01)$ had a significant effect on the total seed bank density and their interaction was not significant ( $p>0.05$; Fig. 1a). Seed densities showed similar patterns over time in cleared and uncleared microsites, being statistically similar $(p>0.05)$ from April through to December 2016 before they started to increase. The effects of bush clearing were more apparent from April to August 2017, with seed densities increasing significantly from 987 to 1872 seeds $\mathrm{m}^{-2}$ in cleared microsites compared with 580 to 1173 seeds $\mathrm{m}^{-2}$ in uncleared microsites (Fig. 1a).

At Kgomokgomo, there were significant interactions $(p<0.001)$ between bush clearing and time on the total seed bank density (Fig. 1b). The seed bank density showed differential responses to time, increasing to 580 and 470 seeds $\mathrm{m}^{-2}$ in cleared and uncleared microsites in August 2016, respectively. In the uncleared microsites, the seed bank densities were slightly increased through 


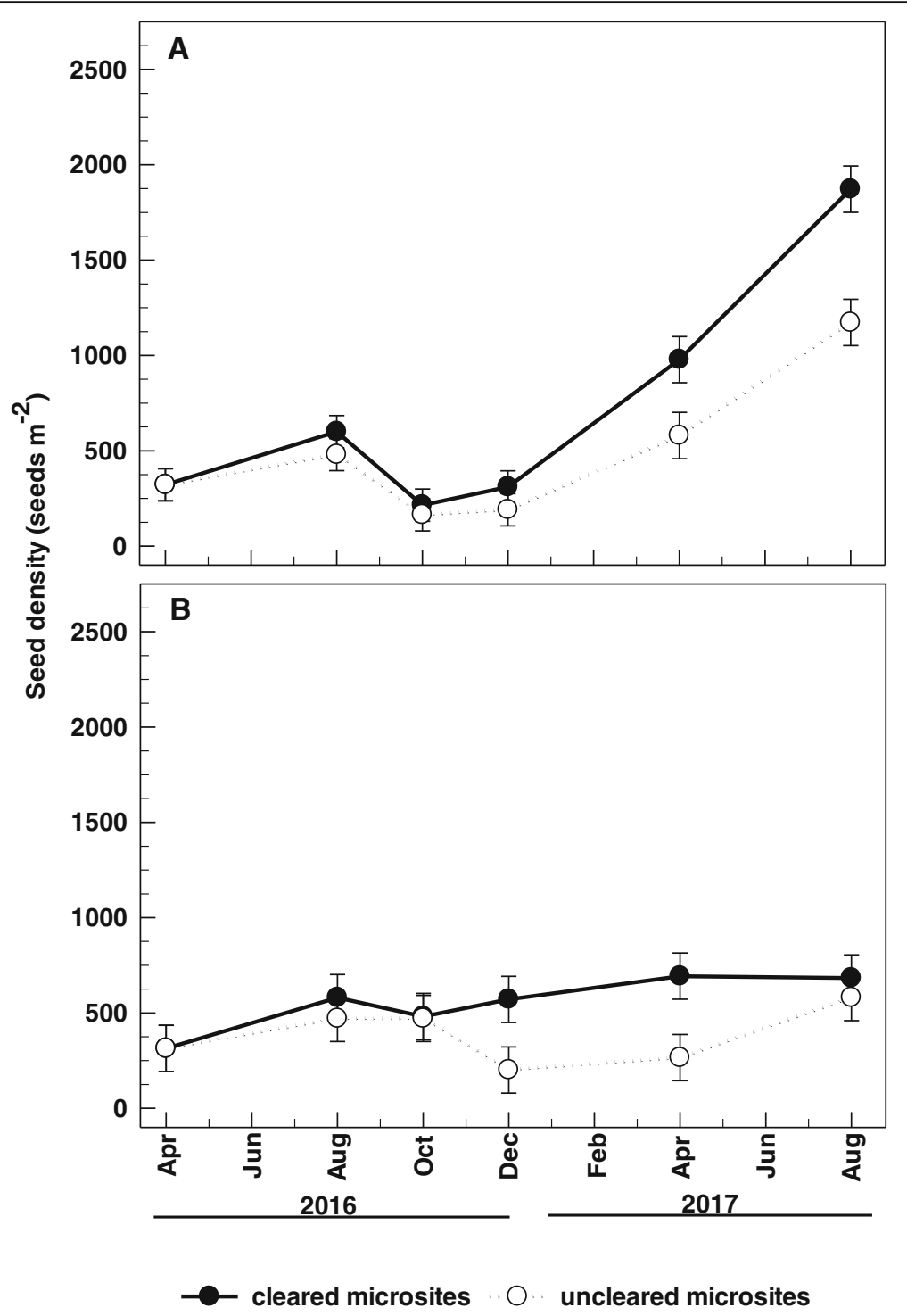

Fig. 1 Total seed density in cleared and uncleared microsites at Maseding (a) and Kgomokgomo (b) rangelands from April 2016 to August 2017. The presented data are back-transformed means and error bars represent \pm standard error of mean

to October 2016 and then there was a sharp decline to 201 seeds $\mathrm{m}^{-2}$ in December 2016. Thereafter, there was a gradual increase to April 2017 followed by a steep increase to 581 seeds $\mathrm{m}^{-2}$ in August 2017. Despite a slight decline in seed bank density from August 2016 to October 2016, the cleared microsites showed a steady increase in SSB density through to August 2017 (Fig. 1b).

\section{Seed bank densities of different plant functional groups} in cleared and uncleared microsites

At Maseding, interaction between microsite types, depth, and time was significant $(p<0.001)$ on the seed densities (Fig. 2). The seed densities of grasses and forbs in cleared and uncleared microsites at $0-10 \mathrm{~cm}$ depth remained similar $(p>0.05)$ until December 2016, beyond which they increased significantly $(p<0.001)$ with time. However, grasses had significantly $(p<0.05)$ higher seed densities than forbs in both cleared and uncleared microsites. At $10-20$ and $20-30 \mathrm{~cm}$ depths, seed densities of grasses and forbs in both cleared and uncleared microsites did not differ $(p>0.05)$ until April 2017 and all were comparable $(p>0.05)$ to pretreatment seed density. Significant differences $(p<0.05)$ between grasses and forbs were only detected in August 2017 at $10-20 \mathrm{~cm}$, with grasses having higher seed densities than forbs in both cleared and uncleared microsites (Fig. 2).

At Kgomokgomo, four plant functional groups (PFGs) emerged from the SBB, namely grasses, forbs, succulents, and sedges (Fig. 3) and the microsite types, depth, and 


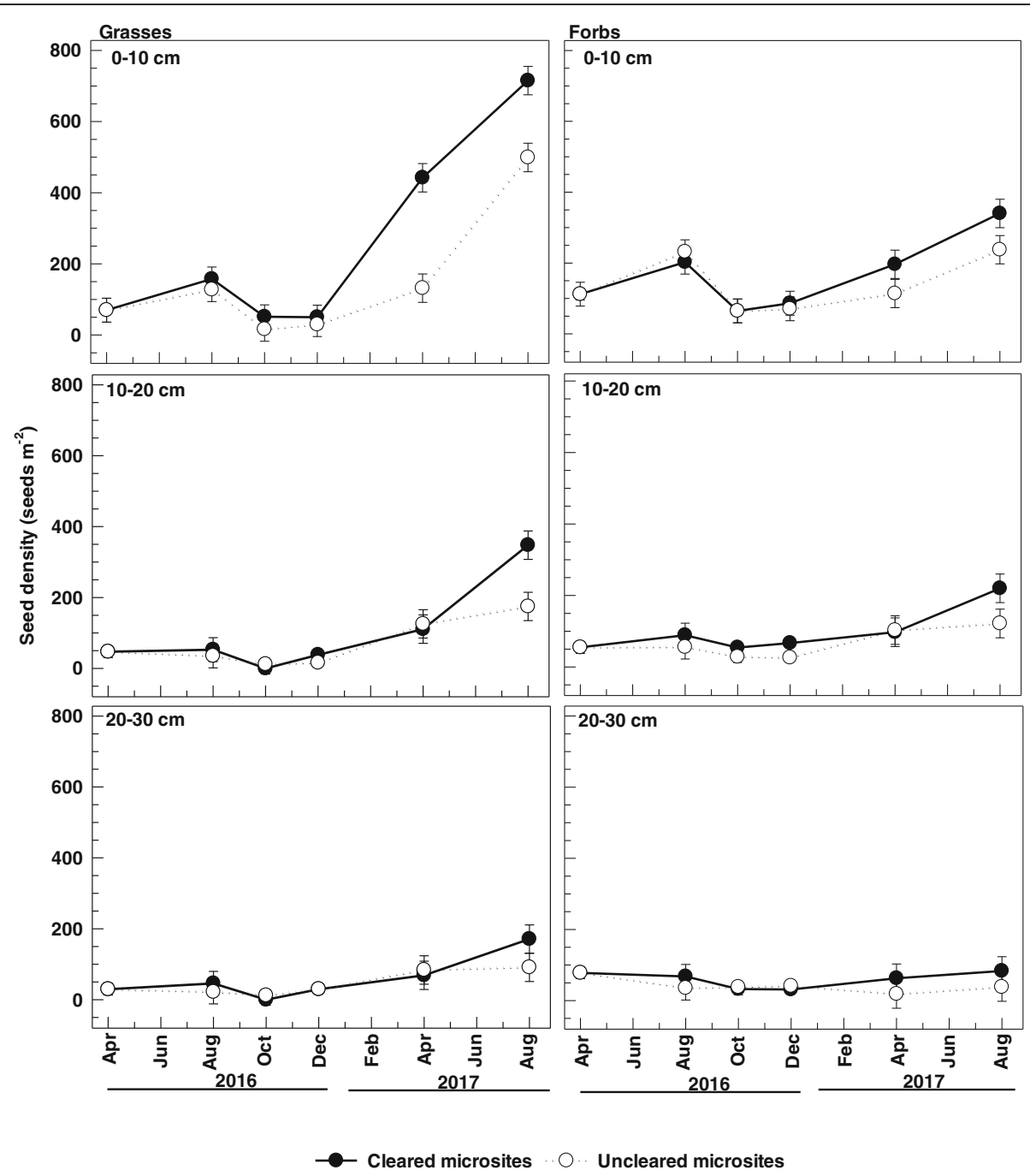

Fig. 2 Soil seed density of grasses and forbs in different soil depths in cleared and uncleared microsites at Maseding from April 2016 to August 2017. The presented data are back-transformed means and error bars represent \pm standard error of mean. At Maseding, only grasses and forbs are presented because no sedges emerged from the SSB and the densities of shrubs, succulents, and legumes were very low $\left(2-6\right.$ seeds $\left.\mathrm{m}^{-2}\right)$

time interaction effects were significant $(p<0.05)$ for all PFGs. There were minor differences on the seed densities of all PFGs at $0-10 \mathrm{~cm}$ between types of microsites up to December 2016. From December 2016 to August 2017, PFGs responded differently (Fig. 3), with seed densities of grasses increasing exponentially in cleared microsites, whereas they remained the same and comparable to pre-treatment density at $0-10 \mathrm{~cm}$ in uncleared microsites (Fig. 3a). The seed densities of grasses at $10-20$ (Fig. 3e) and $20-30 \mathrm{~cm}$ (Fig. 3i) remained similar between microsites except for April 2017 when cleared microsites had higher densities than uncleared microsites. For succulents, seed densities at $0-10 \mathrm{~cm}$ increased significantly $(p<0.05)$ in cleared microsites compared to uncleared microsites in April 2017, whereas uncleared microsites exhibited higher densities in $\mathrm{Au}$ gust 2017 (Fig. 3b). At deeper depths, seed densities of succulents differed $(p<0.05)$ between two microsites only in December 2016 and April 2017 at $10-20 \mathrm{~cm}$ (Fig. 3f, j). Seed densities of forbs (Fig. 3c, g, and k) and sedges (Fig. 3d, h and l) remained comparable between two microsites and were either similar or lower than pre-treatment densities at all burial depths over time.

\section{Soil seed bank composition and richness in cleared and uncleared microsites}

At Maseding, 35 species from 14 families emerged in the SSB, consisting largely of forbs ( $n=15$ species) followed by grasses $(n=12$ species; Table 1$)$. At Kgomokgomo, 26 species from 13 families emerged in the SSB over time (Table 2). Similarly, forbs ( $n=12$ species) was the most dominant functional group followed by grasses $(n=$ 7 species) at Kgomokgomo (Table 2). In both rangelands, species from Poaceae family were most dominant. The 


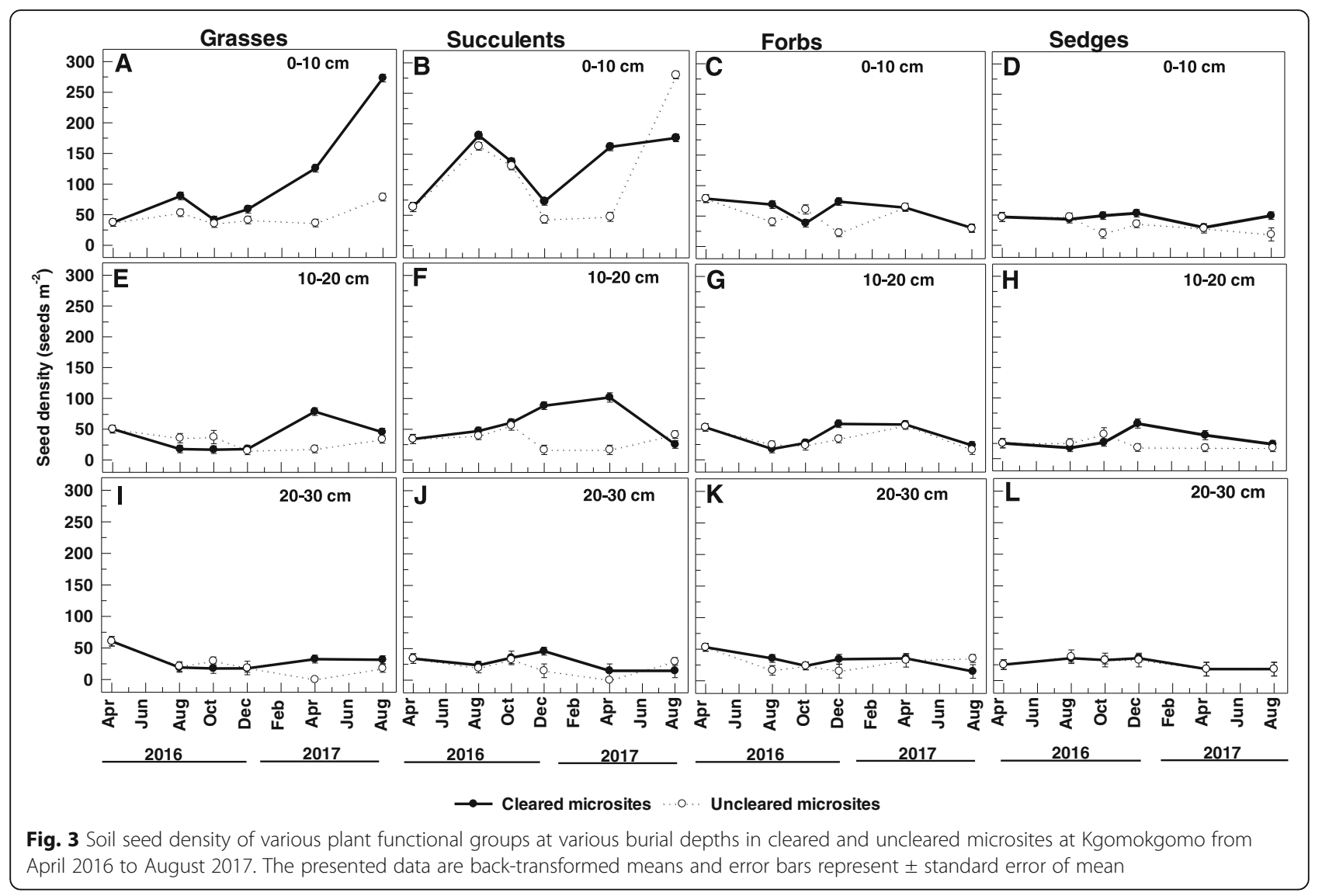

invaders and increaser II species were dominant, and together they accounted for 89 and $92 \%$ at Maseding and Kgomokgomo, respectively (Tables 1 and 2).

At Maseding, perennial species were more abundant (54-84\%) than annuals until April 2017 in cleared microsites. In August 2017, annual species (52\%) had a marginally higher abundance than perennials $(48 \%)$ in cleared microsites. In uncleared microsites, annual species exhibited higher abundance in August 2016; thereafter, their abundance declined to lower levels than that of perennials during the rainy months (October and December 2016). In April and August 2017, annual species attained a marginally higher abundance (>50\%) compared to perennials in uncleared microsites. When microsites were compared, abundance of annuals was comparable between cleared (52\%) and uncleared (51\%) microsites in August 2017 at Maseding. The species richness did not show any significant difference $(p>$ 0.05 ) between cleared and uncleared microsites over time (Table 1). Eragrostis lehmanniana (Nees.) and Jamesbrittenia aurantiaca (Burch.) Hilliard were the most abundant species until December 2016, after which a perennial [Aristida congesta subsp. barbicollis (Roen. \& Schult.)] increased to 31\% in cleared microsites compared to uncleared (12\%) microsites. In contrast, seed bank abundance of $A$. congesta subsp. barbicollis in August 2017 was comparable between cleared (37\%) and uncleared (40\%) microsites (Table 1).

At Kgomokgomo, there was no noticeable change at a life form level as the abundance of annual species was consistently higher than that of perennials both in cleared and uncleared microsites across all sampling times of the year. Bulbostylis hispidula (Vahl.) R.W. Haines, Limeum viscosum (Fenzl.) A. Gay, and Portulaca pilosa (N.E. Br) were the most abundant species until December 2016. Despite dominance of a succulent (Portucala quadrifida L.), palatable grasses [Panicum maximum (Jacq.), Tragus berteronianus (Schult.), and Urochloa mosambicensis (Hack.) Dandy] attained higher abundance in August 2017. There was no significant difference $(p>0.05)$ in species richness of cleared and uncleared microsites at each sampling period at Kgomokgomo (Table 2).

\section{Seed bank diversity in bush-cleared and uncleared microsites}

The repeated measures analysis of variance showed that plant species diversity was significantly affected by bush clearing $(p<0.01)$ and time since bush clearing $(p<$ 0.001) at Maseding (Fig. 4a). However, the interaction of 
Table 1 Plant species abundance (\%) and richness of the soil seed bank over time in bush-cleared and uncleared microsites at Maseding from April 2016 to August 2017

\begin{tabular}{|c|c|c|c|c|c|c|c|c|c|c|c|c|c|c|c|c|}
\hline \multirow[t]{3}{*}{ Species } & \multirow[t]{3}{*}{ Family } & \multirow{3}{*}{$\begin{array}{l}\text { Plant } \\
\text { class }\end{array}$} & \multirow{3}{*}{$\begin{array}{l}\text { Ecological } \\
\text { status }\end{array}$} & \multirow[t]{3}{*}{ LF† } & \multirow[b]{3}{*}{ April } & \multicolumn{6}{|c|}{ Cleared microsites } & \multicolumn{5}{|c|}{ Uncleared microsites } \\
\hline & & & & & & \multicolumn{2}{|c|}{2016} & \multirow{2}{*}{\multicolumn{2}{|c|}{ Dec }} & \multicolumn{2}{|l|}{2017} & \multicolumn{3}{|l|}{2016} & \multicolumn{2}{|l|}{2017} \\
\hline & & & & & & Aug & Oct & & & April & Aug & Aug & Oct & Dec & April & $\overline{\text { Aug }}$ \\
\hline $\begin{array}{l}\text { Achyranthes aspera (L.) } \\
\text { Griseb. }\end{array}$ & Amaranthaceae & Forb & Invader & $P$ & - & 2.7 & 3.3 & - & & - & 1.0 & - & - & - & - & 0.3 \\
\hline $\begin{array}{l}\text { Vachellia tortilis (Forssk.) } \\
\text { Hayne. }\end{array}$ & Fabaceae & Shrub & Encroacher & $\mathrm{D}$ & 4.7 & 1.9 & - & - & & 0.6 & 0.3 & - & - & 1.8 & - & - \\
\hline $\begin{array}{l}\text { Aristida congesta subsp } \\
\text { barbicollis (Roen \& Schult.) }\end{array}$ & Poaceae & Grass & Increaser II & WP & - & - & - & - & & 30.9 & 37.3 & - & - & - & 12.0 & 39.9 \\
\hline $\begin{array}{l}\text { Aristida bipartita (Nees.) } \\
\text { Trin \& Rupr. }\end{array}$ & Poaceae & Grass & Increaser II & $P$ & 2.7 & 9.7 & 5.5 & 8.6 & & 0.6 & 1.4 & 12.0 & 3.8 & 5.4 & 0.6 & - \\
\hline $\begin{array}{l}\text { Amaranthus hybridus (L.) } \\
\text { Timeroy. }\end{array}$ & Amaranthaceae & Forb & Invader & A & 0.7 & - & - & - & & 0.8 & 0.3 & 0.9 & - & - & - & - \\
\hline $\begin{array}{l}\text { Brachiaria eruciformis } \\
\text { (Sibth. \& Sm.) Griseb. }\end{array}$ & Poaceae & Grass & Increaser II & A & - & 1.9 & - & 1.4 & & 12.3 & 10.6 & 2.2 & 4.7 & - & 27.6 & 5.5 \\
\hline $\begin{array}{l}\text { Bothriocloa insculpa } \\
\text { (Hochst.) ex A. Rich. }\end{array}$ & Poaceae & Grass & Increaser II & $P$ & - & 0.8 & 1.1 & - & & 0.4 & 1.0 & 1.3 & - & - & - & - \\
\hline Bidens pilosa (L.) Timeroy. & Asteraceae & Forb & Invader & $A$ & - & 1.2 & - & - & & 0.6 & 14.2 & 0.9 & - & - & 0.3 & 2.0 \\
\hline $\begin{array}{l}\text { Commelina benghalensis } \\
\text { (L.) }\end{array}$ & Commelinaceae & Forb & Invader & $A$ & - & 0.4 & - & - & & - & 0.4 & 0.4 & - & - & 0.6 & 0.3 \\
\hline Chloris virgata (Sw.) & Poaceae & Grass & Increaser II & A & - & - & - & 1.4 & & 4.6 & - & - & - & - & - & - \\
\hline $\begin{array}{l}\text { Chochorous asplenifolius } \\
\text { (Burch.) }\end{array}$ & Malvaceae & Forb & Invader & $P$ & - & - & 3.3 & 11.4 & & 13.9 & 2.1 & 6.2 & 4.7 & 16.1 & 10.2 & 2.8 \\
\hline $\begin{array}{l}\text { Corbichonia decumbens } \\
\text { (Forssk.) Exell. }\end{array}$ & Molluginaceae & Forb & Increaser II & A & - & - & 5.5 & - & & - & 1.1 & 3.6 & 2.8 & 3.6 & - & 3.2 \\
\hline $\begin{array}{l}\text { Crotalaria heidmannii } \\
\text { (Schinz.) }\end{array}$ & Fabaceae & Legume & Increaser II & A & - & - & - & - & & - & - & - & - & - & - & 0.6 \\
\hline $\begin{array}{l}\text { Crabbea angustifolia } \\
\text { (Nees.) Nees. }\end{array}$ & Acanthaceae & Forb & Invader & $P$ & - & - & - & 1.4 & & - & - & - & - & - & - & - \\
\hline Cynodon dactylon (L.) Pers. & Poaceae & Grass & Increaser II & $P$ & - & 1.2 & - & - & & - & - & - & - & - & - & - \\
\hline $\begin{array}{l}\text { Digitaria eriantha (Stent.) } \\
\text { Steud. }\end{array}$ & Poaceae & Grass & Decreaser & $P$ & - & - & - & - & & 5.7 & - & - & - & - & 0.9 & 1.7 \\
\hline $\begin{array}{l}\text { Eragrostis lehmanniana } \\
\text { (Nees.) }\end{array}$ & Poaceae & Grass & Increaser II & $P$ & 29.1 & 22.4 & 22.0 & 22.9 & & 5.5 & 2.8 & 8.4 & 22.6 & 10.7 & 3.3 & 4.2 \\
\hline $\begin{array}{l}\text { Tephrosia purpurea (L.) } \\
\text { Pers. }\end{array}$ & Fabaceae & Legume & Increaser II & $P$ & - & - & - & - & & - & 0.1 & - & - & - & - & - \\
\hline Justicia flava (Vahl.) Vahl. & Acanthaceae & Forb & |ncreaser || & $P$ & - & - & - & - & & 0.2 & 0.1 & 0.9 & - & - & 0.9 & - \\
\hline $\begin{array}{l}\text { Jamesbrittenia aurantiaca } \\
\text { (Burch.) Hilliard. }\end{array}$ & Scrophulariaceae & Forb & Invader & $P$ & 41.2 & 13.1 & 18.7 & 38.6 & & 2.6 & - & 6.7 & 47.2 & 46.4 & 6.3 & - \\
\hline $\begin{array}{l}\text { Kyphorcarpa angustifolia } \\
\text { (Moq.) Lopr. }\end{array}$ & Amaranthaceae & Forb & Invader & A & - & - & - & - & - & - & - & - & 1.9 & 7.1 & - & 1.0 \\
\hline $\begin{array}{l}\text { Kohautia virgata (Willd.) } \\
\text { Bremek }\end{array}$ & Rubiaceae & Forb & Invader & A & - & - & - & - & - & - & - & - & - & - & 0.3 & - \\
\hline $\begin{array}{l}\text { Melinis repens (Willd.) } \\
\text { Zizka. }\end{array}$ & Poaceae & Grass & Invader & WP & - & - & - & - & - & - & - & - & - & - & 0.6 & - \\
\hline $\begin{array}{l}\text { Phyllanthus } \\
\text { maderaspatensis (L.) }\end{array}$ & Phylanthaceae & Forb & Invader & $P$ & - & - & 3.3 & 4.3 & & 4.4 & 2.5 & 3.1 & 3.8 & 1.8 & 8.7 & 0.3 \\
\hline Rhyncosia minima (L.) DC. & Fabaceae & Legume & Increaser II & $P$ & - & - & - & - & - & - & - & - & - & - & - & - \\
\hline $\begin{array}{l}\text { Sesbania bispinosa (Jacq.) } \\
\text { Wight. }\end{array}$ & Fabaceae & Legume & Invader & $A$ & - & - & - & - & - & - & - & - & - & - & - & - \\
\hline $\begin{array}{l}\text { Spermacoce sinensis } \\
\text { (Klotzsch.) Hierm. }\end{array}$ & Rubiaceae & Forb & Invader & A & - & - & - & - & - & - & - & - & - & - & 4.5 & 0.4 \\
\hline
\end{tabular}


Table 1 Plant species abundance (\%) and richness of the soil seed bank over time in bush-cleared and uncleared microsites at Maseding from April 2016 to August 2017 (Continued)

\begin{tabular}{|c|c|c|c|c|c|c|c|c|c|c|c|c|c|c|c|c|}
\hline \multirow[t]{3}{*}{ Species } & \multirow[t]{3}{*}{ Family } & \multirow{3}{*}{$\begin{array}{l}\text { Plant } \\
\text { class }\end{array}$} & \multirow{3}{*}{$\begin{array}{l}\text { Ecological } \\
\text { status }\end{array}$} & \multirow[t]{3}{*}{ LF† } & \multirow[b]{3}{*}{ April } & \multicolumn{6}{|c|}{ Cleared microsites } & \multicolumn{5}{|c|}{ Uncleared microsites } \\
\hline & & & & & & \multicolumn{2}{|c|}{2016} & \multirow{2}{*}{\multicolumn{2}{|c|}{ Dec }} & \multicolumn{2}{|l|}{2017} & \multicolumn{3}{|l|}{2016} & \multicolumn{2}{|l|}{2017} \\
\hline & & & & & & Aug & Oct & & & April & Aug & Aug & Oct & Dec & April & Aug \\
\hline $\begin{array}{l}\text { Sorghum versicolor } \\
\text { (Andersson.) }\end{array}$ & Poaceae & Grass & Decreaser & $P$ & - & - & - & - & - & - & - & - & - & - & - & - \\
\hline $\begin{array}{l}\text { Schkuhria pinnata (L.) } \\
\text { Kuntze ex Thell. }\end{array}$ & Asteraceae & Forb & Invader & A & - & - & 12.1 & 1.4 & & 7.5 & 12.0 & 40.4 & 0.9 & 5.4 & 11.7 & 11.5 \\
\hline Sonchus asper (L.) Hill. & Asteraceae & Forb & Invader & A & 18.9 & 0.8 & - & - & - & - & - & - & - & - & - & - \\
\hline $\begin{array}{l}\text { Tragus berteronianus } \\
\text { (Schult.) }\end{array}$ & Poaceae & Grass & Increaser || & A & 0.7 & 6.9 & 12.1 & - & - & 4.8 & 12.0 & 6.2 & 7.5 & - & 7.5 & 18.0 \\
\hline -Tribulus terrestris (L.) Oliv. & Zygophyllaceae & Forb & Increaser II & A & - & - & - & - & - & - & - & - & - & - & - & - \\
\hline Hibiscus trionum L. & Malvaceae & Forb & Invader & A & - & - & - & - & - & - & - & 0.4 & - & - & 2.4 & - \\
\hline Portulaca quadrifida L. & Portulacaceae & Succulent & Invader & A & - & - & - & - & - & - & - & 1.3 & - & - & - & 8.2 \\
\hline $\begin{array}{l}\text { Urochloa mosambicensis } \\
\text { (Hack.) Dandy. }\end{array}$ & Poaceae & Grass & Increaser I| & A & - & - & - & - & - & - & - & - & - & - & 1.2 & - \\
\hline $\begin{array}{l}\text { Total abundance of } \\
\text { herbaceous perennials (\%) }\end{array}$ & & & & & 73 & 53.4 & 57.2 & 86.1 & & 64.2 & 48.4 & 39 & 82.1 & 80.4 & 43.5 & 48.9 \\
\hline $\begin{array}{l}\text { Total abundance of } \\
\text { herbaceous annuals (\%) }\end{array}$ & & & & & 22.3 & 44.7 & 42.8 & 13.9 & & 35.2 & 51.5 & 60.7 & 17.9 & 19.6 & 56.5 & 51.1 \\
\hline $\begin{array}{l}\text { Species richness (number } \\
\text { of species) }\end{array}$ & & & & & 8 & 17 & 13 & 12 & & 20 & 20 & 18 & 10 & 10 & 18 & 16 \\
\hline
\end{tabular}

${ }^{\dagger}$ LF (life form): $D$ deciduous, $E$ evergreen, WP weak perennial, $A$ annual, and $P$ perennial, Apr April, Aug August, Oct October, Dec December

the two factors was not significant $(p>0.05)$. The species diversity followed similar trends in both microsites, with cleared microsites having higher species diversity than uncleared microsites in August, October, and December 2016. In April and August 2017, species diversity was not significantly $(p>0.05)$ different between two microsites (Fig. 4a).

At Kgomokgomo, bush clearing had a significant effect $(p<0.05)$ on species diversity. However, the interaction of time and bush clearing was not significant $(p>0.05$; Fig. $4 \mathrm{~b})$. The effects of bush clearing were not apparent up to December 2016, with cleared and uncleared microsites depicting similar response trends over time. In April 2017, species diversity declined significantly $(p<0.05)$ in uncleared microsites $(H=1.1)$ compared to cleared microsites $(H=2.0)$. Species diversity remained steady $(H=2.0$ to 2.1) from April to August 2017 in cleared microsites, and it was consistently higher relative to uncleared microsites (Fig. 4b). Surprisingly, regardless of a decline in species richness to 14 species in August 2017 (Table 2), species diversity remained high and comparable to that of December 2016 and April 2017 at Kgomokgomo.

\section{Similarity between SSB and AGV in the cleared and uncleared microsites}

The interaction between treatment and time was significant $(p<0.05)$ on the similarity between SSB and AGV at Maseding (Fig. 5a). The similarity between SSB and AGV showed similar response patterns over time in cleared and uncleared microsites, with Sørensen's coefficients being statistically similar $(p>0.05)$ between microsites until April 2017. From April to August 2017, Sørensen's similarity increased significantly from 0.62 to 0.66 in cleared microsites and declined from 0.58 to 0.50 in uncleared microsites (Fig. 5a). The Sørensen's similarity linearly positively correlated with species richness in cleared $\left(r^{2}=0.95, p<0.001\right)$ and uncleared $\left(r^{2}=0.91, p<\right.$ $0.01)$ microsites over time at Maseding.

At Kgomokgomo, treatment $(p<0.05)$ and time $(p<$ 0.05 ) had significant effects on the similarity between SSB and AGV (Fig. 5b). However, their interaction was not significant $(p>0.05)$. Sørensen's similarity index followed similar response patterns characterised by relatively low coefficients of 0.23 to 0.28 in cleared microsites and 0.17 to 0.29 in uncleared microsites from April to December 2016. From December 2016 to August 2017, similarity increased linearly to 0.52 in cleared microsites and it was significantly higher $(p<0.05)$ than that in uncleared microsites (0.34; Fig. $5 b)$.

\section{Discussion}

Total soil seed bank density in the cleared and uncleared microsites

The higher densities in cleared microsites compared to uncleared microsites are, according to Godefroid et al. (2006), due to reduced woody canopies in the cleared microsites that allow more plant recruitment, thereby increasing seed production. The seed bank densities 
Table 2 Plant species abundance (\%) of the soil seed bank over time in bush-cleared and uncleared microsites at Kgomokgomo from April 2016 to August 2017

\begin{tabular}{|c|c|c|c|c|c|c|c|c|c|c|c|c|c|c|c|}
\hline \multirow[t]{3}{*}{ Species } & \multirow[t]{3}{*}{ Family } & \multirow{3}{*}{$\begin{array}{l}\text { Plant } \\
\text { class }\end{array}$} & \multirow{3}{*}{$\begin{array}{l}\text { Ecological } \\
\text { status }\end{array}$} & \multirow[t]{3}{*}{ LF† } & \multirow[b]{3}{*}{ April } & \multicolumn{5}{|c|}{ Cleared microsites } & \multicolumn{5}{|c|}{ Uncleared microsites } \\
\hline & & & & & & \multicolumn{3}{|c|}{2016} & \multicolumn{2}{|l|}{2017} & \multicolumn{3}{|c|}{2016} & \multicolumn{2}{|l|}{2017} \\
\hline & & & & & & $\overline{\text { Aug }}$ & Oct & Dec & April & $\overline{A u g}$ & $\overline{\text { Aug }}$ & Oct & Dec & April & $\overline{\text { Aug }}$ \\
\hline $\begin{array}{l}\text { Achyranthes aspera (L.) } \\
\text { Griseb. }\end{array}$ & Amaranthaceae & Forb & Invader & $P$ & - & - & - & 1.3 & 0.4 & - & 1.4 & 1.5 & - & - & - \\
\hline $\begin{array}{l}\text { Aloe greatheadii var davyana } \\
\text { (Schönl.) }\end{array}$ & Asphodelaceae & Succulent & Increaser I| & $E$ & - & 0.5 & 3.3 & 2.7 & - & - & - & 6.2 & 4.4 & - & - \\
\hline $\begin{array}{l}\text { Bulbostylis hispidula (Vahl.) R. } \\
\text { W. Haines. }\end{array}$ & Cyperaceae & Sedge & Increaser II & A & 39.2 & 13.4 & 25.7 & 15.4 & 7.9 & 6.6 & 9.8 & 46.2 & 9.2 & 9.7 & 2.7. \\
\hline $\begin{array}{l}\text { Chochorous } \\
\text { longipedunculatus (Burch.) }\end{array}$ & Malvaceae & Forb & Increaser II & $P$ & - & 4.0 & - & 2.0 & 6.2 & 0.4 & 6.3 & - & 5.7 & 38.7 & 0.7 \\
\hline Crotalaria lotoides (Benth.) & Fabaceae & legume & Increaser II & A & - & 0.5 & - & 0.7 & 0.4 & - & - & - & - & 1.6 & 0.7 \\
\hline Cynodon dactylon (L.) Pers. & Poaceae & Grass & Increaser II & $A$ & 2.5 & 1.5 & - & 0.7 & - & - & 0.7 & - & 0.9 & - & - \\
\hline $\begin{array}{l}\text { Digitaria eriantha (Stent.) } \\
\text { Steud. }\end{array}$ & Poaceae & Grass & Decreaser & $P$ & 1.6 & 1.0 & - & 0.7 & 4.5 & 3.3 & - & - & - & 1.6 & - \\
\hline $\begin{array}{l}\text { Eragrostis pseudosclerantha } \\
\text { (Chiov.) }\end{array}$ & Poaceae & Grass & Increaser II & $P$ & - & 2.5 & 2.0 & - & 2.9 & 7.0 & 1.4 & - & 6.1 & - & - \\
\hline Eragrostis spp. & Poaceae & Grass & Increaser II & $P$ & 13.3 & 10.0 & 10.5 & 11.4 & 1.2 & 5.8 & 11.2 & 7.7 & 11.8 & - & 3.4 \\
\hline Evolvulus alsinoides L. & Colvolvulaceae & Forb & Increaser II & A & - & - & 3.9 & 2.0 & 0.8 & - & - & - & - & - & - \\
\hline Hibiscus engleri (K. Schum.) & Malvaceae & forb & Invader & A & - & - & - & - & 2.5 & 0.8 & - & - & - & 8.1 & \\
\hline $\begin{array}{l}\text { Ipomoa sinensis (Desr.) } \\
\text { Choisy. }\end{array}$ & Convolvulaceae & Forb & Invader & A & - & 1.5 & 0.7 & 0.7 & 2.1 & 2.9 & - & - & 0.9 & 1.6 & 0.7 \\
\hline Justicia flava (Vahl.) Vahl. & Acanthaceae & Forb & Increaser II & $P$ & - & - & 0.7 & 0.7 & - & - & - & - & - & - & - \\
\hline $\begin{array}{l}\text { Kohautia virgata (Willd.) } \\
\text { Bremek }\end{array}$ & Rubiaceae & Forb & Invader & A & - & - & 0.7 & 2.7 & - & - & - & - & - & - & - \\
\hline $\begin{array}{l}\text { Kyphorcarpa angustifolia } \\
\text { (Moq.) Lopr. }\end{array}$ & Amaranthaceae & Forb & Invader & A & - & - & 7.2 & 1.3 & 0.4 & 0.8 & - & 1.5 & - & 1.6 & - \\
\hline $\begin{array}{l}\text { Limeum viscosum (Fenzl.) A. } \\
\text { Gay. }\end{array}$ & Molluginaceae & Forb & Increaser || & A & 1.6 & 25.4 & 21.1 & 8.1 & 0.4 & 1.2 & 5.6 & 4.6 & 33.2 & 4.8 & 2.0 \\
\hline Panicum maximum (Jacq.) & Poaceae & Grass & Decreaser & $P$ & - & 1.0 & 3.3 & - & 15.7 & 11.0 & 1.4 & - & 3.1 & 11.3 & 12.9 \\
\hline $\begin{array}{l}\text { Phyllanthus maderaspatensis } \\
\text { L. }\end{array}$ & Phylanthaceae & Forb & Invader & $P$ & - & - & - & 0.7 & - & - & 2.8 & 1.5 & - & 3.2 & - \\
\hline $\begin{array}{l}\text { Portulaca hereroensis } \\
\text { (Schinz.) }\end{array}$ & Portulacaceae & Succulent & Invader & A & 3.3 & 2.0 & - & 2.7 & - & - & 1.4 & - & 4.4 & - & - \\
\hline Portulaca pilosa (N. E. Br.) & Portulacaceae & Succulent & Invader & A & 7.5 & 24.4 & 17.1 & 30.2 & 8.7 & 3.7 & 42.0 & 24.6 & 17.9 & 1.6 & 4.1 \\
\hline Portulaca quadrifida L. & Portulacaceae & Succulent & Invader & A & - & 10.0 & 3.3 & 16.1 & 27.3 & 24.0 & 6.3 & 1.5 & 1.3 & 12.9 & 49.0 \\
\hline $\begin{array}{l}\text { Schkuhria pinnata (L.) } \\
\text { Kuntze ex Thell. }\end{array}$ & Asteraceae & Forb & Invader & A & - & - & 0.7 & - & 0.8 & - & 0.7 & - & 0.9 & - & - \\
\hline Sonchus asper (L.) Hill. & Asteraceae & Forb & Invader & $A$ & 22.5 & - & - & - & - & - & - & - & - & - & - \\
\hline $\begin{array}{l}\text { Tragus berteronianus } \\
\text { (Schult.) }\end{array}$ & Poaceae & Grass & Increaser II & A & 0.8 & 1.0 & 0.7 & - & 12.4 & 13.0 & 3.5 & & 0.4 & 1.6 & 10.9 \\
\hline Tephrosia purperea (L.) Pers. & Fabaceae & Legume & Increaser II & A & - & 0.5 & - & - & - & - & 2.8 & 3.1 & - & 1.6 & 1.4 \\
\hline $\begin{array}{l}\text { Urochloa mosambicensis } \\
\text { (Hack.) Dandy. }\end{array}$ & Poaceae & Grass & Increaser II & $A$ & - & - & - & - & 5.0 & 17.8 & 2.8 & - & - & - & 11.6 \\
\hline $\begin{array}{l}\text { Total abundance of } \\
\text { herbaceous perennials (\%) }\end{array}$ & & & & & 13.3 & 42.7 & 15.8 & 14.4 & 26 & 24.8 & 24.5 & 10.5 & 26.7 & 53.2 & 17 \\
\hline $\begin{array}{l}\text { Total abundance of } \\
\text { herbaceous annuals (\%) }\end{array}$ & & & & & 86.7 & 56.9 & 84.2 & 82.9 & 74 & 75.2 & 75.7 & 83.3 & 68.9 & 46.8 & 83 \\
\hline $\begin{array}{l}\text { Species richness (number of } \\
\text { species) }\end{array}$ & & & & & 9 & 16 & 15 & 18 & 18 & 14 & 16 & 10 & 14 & 14 & 12 \\
\hline
\end{tabular}




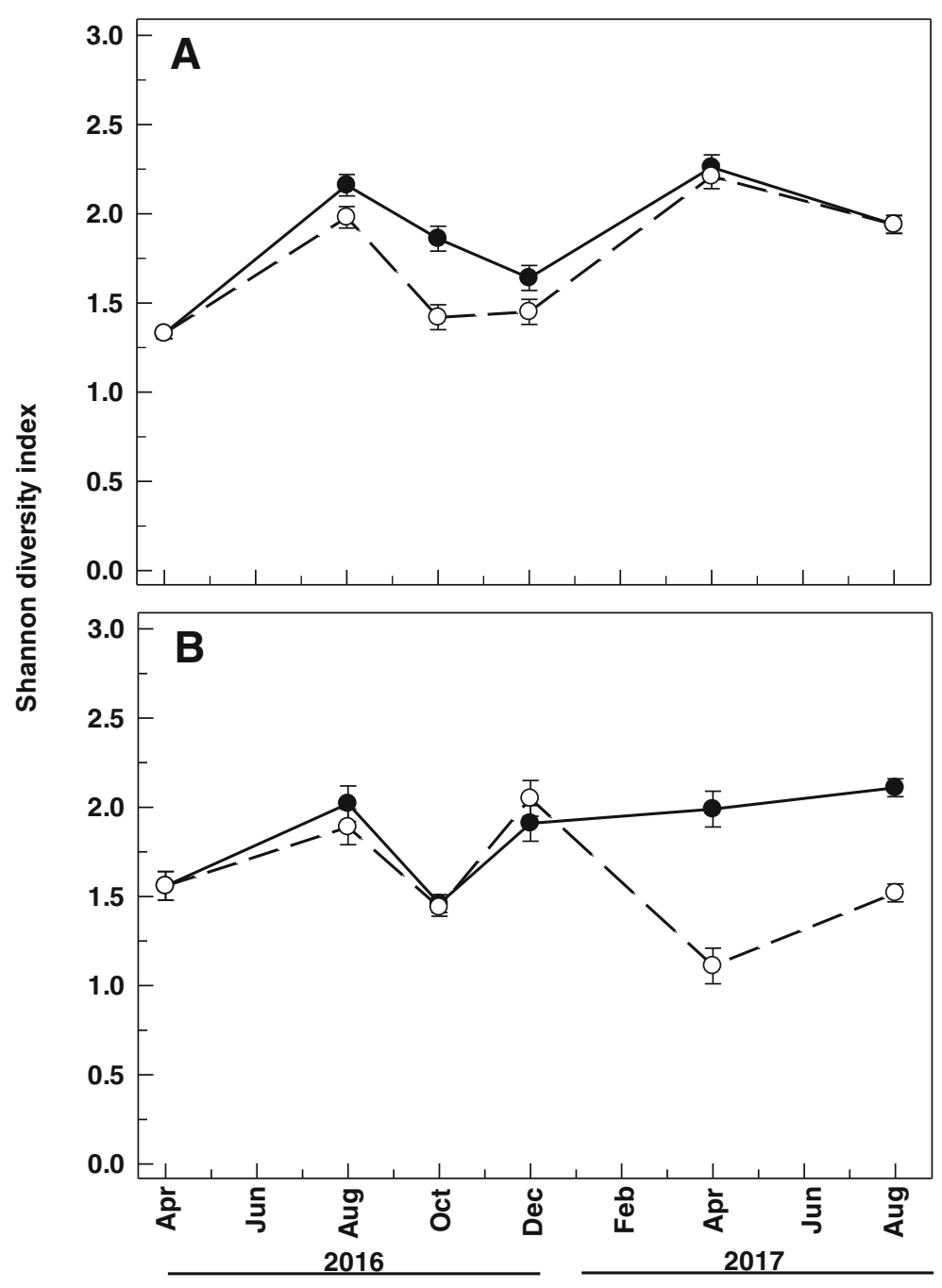

Cleared microsites $--\mathrm{O}-$ Uncleared microsites

Fig. 4 Plant diversity in cleared and uncleared microsites at Maseding (a) and Kgomokgomo (b) from April 2016 to August 2017. The presented data are back-transformed means and error bars represent \pm standard error of mean

recorded in August 2017 at Maseding are generally comparable to those reported by Sakai et al. (2005) but lower than those reported by Bisteau and Mahy (2005) in bush-cleared areas. Although bush clearing had significant effects, our results indicated that seasonality was also a paramount determinant of the seed bank size. In both microsites, seed densities declined significantly during rainy season (October and December), probably due to germination in the rangelands, which subsequently increased SSB densities in April and August 2017, more significantly in cleared microsites relative to uncleared microsites. The depletion of the seed bank during rainy months indicated that the seed bank was transient and that the seed bank in April and August 2017 was derived from the seed rain, confirming that passive restoration depends partly on seed production of the extant vegetation. At Kgomokgomo, differential responses of seed densities were evident in December 2016, with seed densities increasing in cleared microsites whereas they continued to decline in uncleared microsites. The annual species produce seeds very early around December in semi-arid southern Africa (Veenendaal et al. 1996), with the dormancy of some seeds breaking immediately after seed set (Baskin and Baskin 2014). High light intensity in cleared microsites might have facilitated early seed maturity and dormancy breakup. 


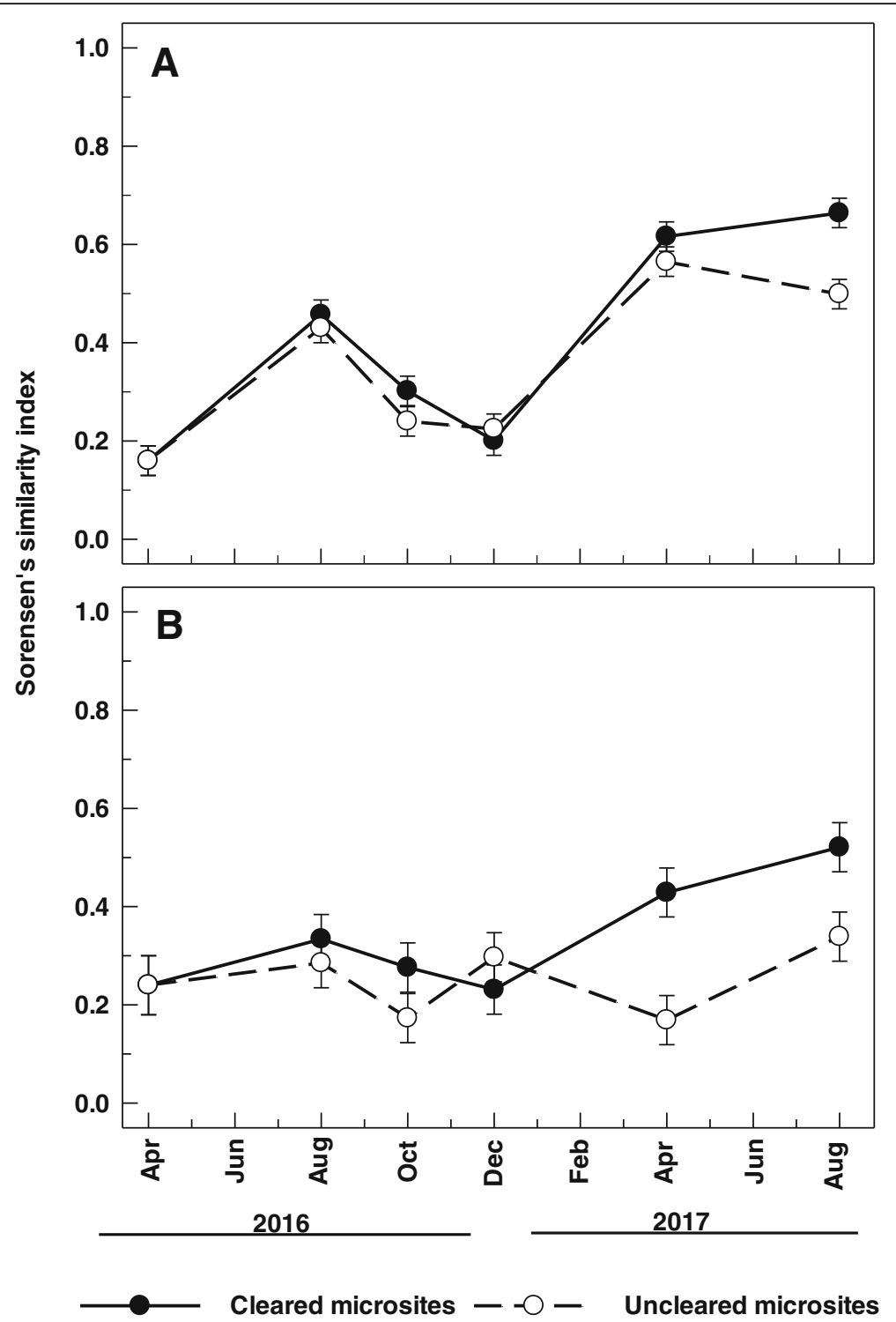

Fig. 5 Similarity index between soil seed bank and aboveground vegetation in cleared and uncleared microsites at Maseding (a) and Kgomokgomo (b) from April 2016 to August 2017. The presented data are back-transformed means and error bars represent \pm standard error of mean

\section{Soil seed bank densities of different plant functional} groups in the cleared and uncleared microsites

The higher seed densities consisting mostly of grasses were retained at $0-10 \mathrm{~cm}$ in April and August 2017, with densities declining with an increase in burial depth (Figs. 2 and 3). These seed distribution patterns are similar to those reported by Dolle and Schmidt (2009) and Farnsworth et al. (2012). In our study, the burial of seeds could be attributable to self-mulching that occurs when vertic clays (soil type at Maseding) shrink and swell, thereby depositing seeds into the soil cracks (Espinar and Clemente 2007). At Kgomokgomo, however, deep burial of seeds might be due to deposition of sand in large quantities during flooding and wind erosion. Low seed bank size of grasses in uncleared microsites is in line with Bakker et al. (1996) who reported that bush encroachment reduced soil seed bank size. Low seed production and poor establishment of plants underneath woody canopies as a result of low light are the main causes of low seed bank densities (Bakker et al. 2014). In cleared microsites, large seed densities of grasses, mostly those retained in the top layer are likely to facilitate passive restoration because they are close to the soil surface where temperature variation and soil moisture are high. This was corroborated by a decline in seed bank densities at $0-10 \mathrm{~cm}$ during October and December 2016 
(Figs. 2 and 3), indicating that most grass seeds were already germinated in the rangelands during these months. The seeds retained in the top layer are transient (Dolle and Schmidt 2009), and they likely represented seed production of the 2017 reproductive season. However, large densities of succulent seeds in April 2017 at $0-10 \mathrm{~cm}$ in cleared microsites compared to uncleared microsites indicated that more seeds were dropped later in uncleared microsites compared to cleared microsites. This might indicate that high light availability in cleared microsites hastened seed production, maturity, and dormancy breakup earlier than in uncleared microsites. Seed densities remained low and statistically similar at deeper depths $(10-20$ and $20-30 \mathrm{~cm})$ over time at both Maseding and Kgomokgomo except for grasses in August 2017 in cleared microsites at Maseding. The consistently low seed bank densities at deeper depths suggested that there were relatively few seeds buried to deeper depths. These consistent trends indicated that deeper depths consisted of persistent seed bank, hence seed densities were statistically similar across all sampling times at 10-20 and 20-30 cm (Figs. 2 and 3). The deeply buried seeds remain dormant for a long period because light as a germination cue does not penetrate too deep in the soil (Benvenuti et al. 2001).

\section{Soil seed bank composition and richness in the cleared and uncleared microsites}

Higher abundance of invasive species and increaser II species at Maseding and Kgomokgomo rangelands suggested that these rangelands previously experienced an anthropogenic disturbance. According to van der Walt (2009), most of the invaders and increaser II species emerged in the SSB are weeds of croplands, indicating that these rangelands are abandoned cultivated lands that were encroached by woody plants following abandonment. A lack of differences in species richness between microsites over time at Maseding and Kgomokgomo corroborated reports of Korb et al. (2005) who found no changes in species richness 18 months after thinning of woody plants. Species richness also did not change 24 months after woody plant clearing in the study by Arevalo et al. (2016). In this study, we infer that, a year and 4 months for which the seed bank was assessed was not long enough for bush clearing to significantly alter the SSB species richness. The legacy effects of cleared woody plants on the soil seed bank can persist a little longer depending on the type of cleared species (Maclean et al. 2018) and site-specific conditions. Although species richness did not change significantly, a noticeable increase in abundance of annual species to levels comparable to perennials occurred in August 2017 in cleared microsites at Maseding. This increase was mainly attributed to $B$. eruciformis, $T$. berteronianus,
Bidens pilosa (L.) Timeroy, and Schkuhria pinnata (L.) Kuntze ex Thell (Table 1). The increase in abundance of annual grasses (B. eruciformis and T. berteronianus) and a perennial (A. congesta subsp. barbicollis) in cleared microsites suggested that passive restoration is possible, but it will commence at lower seral stages of succession. These species are highly important for soil stabilisation against erosion and soil improvement for colonisation by perennial species (van Oudtshoorn 1999). The early successional species produce many seeds that colonise vigorously in high light on disturbed sites (Tiebel et al. 2018). The increase in the seed bank abundance of annual species over time together with increase in similarity between SSB and AGV suggested that passive restoration depended largely on aboveground vegetation. Management of the aboveground vegetation is therefore key for passive restoration following bush clearing. In this study, the increase in the seed bank abundance of herbaceous species with time was aided by protection of cleared sites through fencing with cleared woody material. Protection from grazing is encouraged to allow regeneration and may also be important for driving continuous successional changes towards higher seral stages of succession. Fencing following bush clearing is also important for protecting floral parts of aboveground vegetation from grazing, thereby ensuring high seed production. Moreover, spreading branches of cleared woody plants, termed brush-packing, may also be useful not only for increasing seed production but also protection of seedlings from trampling and increasing infiltration, thereby ensuring successful seedling emergence and establishment (Mndela et al. 2019). The two forbs ( $B$. pilosa and $S$. pinnata) are invaders and may exacerbate ecosystem degradation through competing with indigenous species for resources. These invaders colonise vigorously in bush-cleared areas, especially in bare trampled patches, hence they require close monitoring and eradication (Potgieter et al. 2017). As shown in Table 1, the seed bank of the two invaders was heavily depleted during rainy months (October and December), indicating that they produce transient seeds. Thus, removal of their seedlings during the rainy season can be useful in preventing their spread in the aboveground vegetation which might in turn favour passive restoration. The low abundance of $A$. congesta subsp. barbicollis in April 2017 in uncleared microsites compared to cleared microsites suggested that more seeds were dropped much later after sampling in uncleared microsites. Moreover, A. congesta subsp. barbicollis did not emerge in the SSB until December 2016, indicating that this species produced non-viable seeds or did not produce seeds at all in 2016 (Table 1). Therefore, it is highly likely that the increase in seed bank abundance of this species in August 2017 was driven by seed dispersal into cleared 
sites. The higher abundance of a perennial grass $(P$. maximum) and two annual species ( $T$. berteronianus and $U$. mosambicensis) at Kgomokgomo in August 2017 (Table 2) suggested that bush clearing may promote passive restoration, but low abundance of perennial grasses may delay vegetation recovery. The low abundance of perennials in the soil seed bank has been reported in previous studies and has been associated with production of few and transient seeds (Tedder et al. 2012).

\section{Soil seed bank diversity in the cleared and uncleared microsites}

At Maseding, the decline in the diversity in August 2017 was probably due to the dominance of a few species including A. congesta subsp. barbicollis, T. berteronianus, B. pilosa and S. pinnata in both microsites (Table 1). The decline in diversity reflects a lack of propagule dispersal of new species into cleared microsites and inability of other local species to incorporate seeds into the SSB. The dominant species (A. congesta subsp. barbicollis) on the SSB was also abundant in the AGV in both microsites, but more so in cleared than in uncleared microsites (Additional file 1: Table S1). The long awns and sharp callus on the seeds of Aristida species enable epichorous and anemochorous dispersal (Mbaluka 2015), resulting in this species being homogenously distributed in space and time. A statistically similar diversity in thinned and unthinned woodlands 3 years after woody plant thinning was also reported by Schelling and McCathy (2007). Regardless of a decline in species richness in August 2017 at Kgomokgomo, diversity remained high, due partly to increase in abundance of other species, e.g. U. mosambicensis (Table 2). The increase in abundance of these species reduced the dominance of few species, thereby slightly increasing the diversity. These results implied that increase in diversity does not depend only on increase in species richness, but also on the increase in seed production of other species which subsequently balances the abundance of different species.

\section{Similarity between SSB and AGV in the cleared and uncleared microsites}

The linear correlation between Sørensen's similarity and species richness at Maseding indicated that increase in number of species contributing to the seed bank over time resulted in increase in the number of species shared between SSB and AGV. However, all species that emerged in the SSB were recorded in the AGV, whereas some species recorded in the AGV were absent in the SSB. Our results highlighted that effective passive restoration soon after bush clearing depends upon seed production, particularly of early successional species rather than persistent seed bank. Under these circumstances, post-clearing management of aboveground vegetation including protection of already existing vegetation is key to increase seed production and species richness (Abella and Springer 2008). In general, similarity between SSB and AGV at Kgomokgomo was low although it increased with time in cleared microsites (Fig. 5b). Some legumes e.g. Chamaecrista and Crotalaria spp. and other grass species were only recorded in the AGV at low abundance (Additional file 1: Table S2). The seeds of these species were less likely to be captured during sampling due to low abundance, small spatial area of the sampling equipment and possibly lack of long-distance dispersal. The consistently higher abundance of annuals over time in the SSB at Kgomokgomo (Table 2) suggested that perennials had minimal contribution to the SSB. This is likely because most of perennial species utilise vegetative more than sexual reproduction (Tedder et al. 2012), and their large sized seeds are highly vulnerable to predation (Gomaa 2012).

\section{Conclusions}

Bush clearing increased seed bank densities, largely of grasses, indicating potential for passive restoration from the soil seed bank. However, passive restoration following bush clearing is likely to be initiated by early successional species, mostly annuals and weak perennials. Invasion of the SSB by $B$. pilosa and $S$. pinnata at Maseding and Portulaca spp. at Kgomokgomo showed that passive restoration might be hampered, hence close monitoring and eradication of these species is required following bush clearing. Bush clearing also increased similarity between SSB and AGV over time, probably due to increases in species richness over time. The tendency of SSB resembling AGV over time in cleared microsites signified that seed production from $A G V$ is important for passive restoration following bush clearing. Therefore, post-clearing management should be planned to improve seed production of already existing vegetation to ensure high seed bank size that will ensure high vegetation recruitment.

\section{Supplementary information}

Supplementary information accompanies this paper at https://doi.org/10. 1186/s13717-019-0204-6.

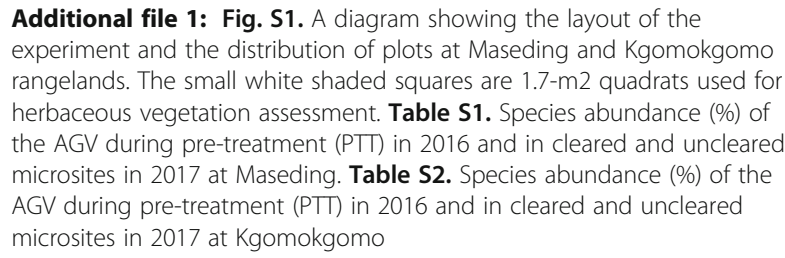

Abbreviations

AGV: Aboveground vegetation; GLM: General linear model; PFGs: Plant functional groups; RMANOVA: Repeated measures analysis of variance; SAS: Statistical analysis system; SSB: Soil seed bank 


\section{Acknowledgements}

Authors extend their gratitude to Mr M Mangwane, T Magandana, T Matlala, B Bonzana and F Tlako for their assistance during vegetation surveys and soil sampling. Thanks to Mr France Mpuloane for allowing us to conduct the research at these rangelands which were under his bush control project.

\section{Authors' contributions}

All authors designed the study and MM collected the field data and conducted glasshouse experiments. MM and ICM analysed the data and MM wrote the manuscript. ICM, FN and SD reviewed and provided valuable comments on the manuscript. All authors approved the manuscript for publication.

\section{Author information}

M. Mndela is a Ph.D. student at the University of Pretoria, pursuing his Ph.D. degree in pasture/rangeland science. Dr I.C. Madakadze is a senior lecturer at the University of Pretoria and he supervises the corresponding author. Dr F. Nherera-Chokuda was working as a dairy nutritionist researcher at ARC at the time of this research and is currently working as a research specialist at the National Emegent Meat Producers Organisation (NERPO) of South Africa. Professor S. Dube is a specialist researcher under rangeland section at the International Livestock Research Institute (ILRI). Dr F. Nherera-Chokuda and Professor S. Dube are co-supervisors of the Ph.D. work of M. Mndela.

\section{Funding}

This research was supported by the Agricultural Research Council (MMN 3014) and National Research Foundation (NRF) of South Africa.

\section{Availability of data and materials}

The data used for this study could be made available on request and discussion with authors.

\section{Ethics approval and consent to participate}

Not applicable.

\section{Consent for publication}

Not applicable.

\section{Competing interests}

The authors declare that they have no competing interests.

\section{Author details}

${ }^{1}$ University of Pretoria, P/Bag X20, Hatfield, Pretoria 0028, South Africa. ${ }^{2}$ Agricultural Research Council, API, P/Bag X02, Irene, Pretoria 0062, South Africa. ${ }^{3}$ International Livestock Research Institute (ILRI), P. O. Box MP163, Mount Pleasant, Harare, Zimbabwe.

\section{Received: 9 July 2019 Accepted: 14 November 2019}

Published online: 03 January 2020

\section{References}

Abella SR, Chiquoine LP, Vanier CH (2013) Characterizing soil seed banks and relationships to plant communities. Plant Ecol 214:703-715

Abella SR, Springer JD (2008) Estimating soil seed bank characteristics in ponderosa pine forests using vegetation and forest-floor data. United States Department of Agriculture Forest Service. Research Note RMRS-RN-35.

Archer SR, Predick KI (2014) An ecosystem services perspective on brush management: research priorities for competing land-use objectives. J Ecol 102:1394-1407

Arevalo B, Valladarez-Cob JG, Muschamp S, Kay E, Finkral A, Roopsind A, Putz FE (2016) Effects of reduced-impact selective logging on palm regeneration in Belize. Forest Ecol Manage 369:155-160

Bakker JP, Bakker ES, Rosen E, Verweig GL, Bekker RM (1996) The soil seed bank composition along a gradient from dry alvar grassland to Juniperus scrubland. J Veg Sci 7:165-176

Bakker JP, Hoffman F, Ozinga WM, Rosen E (2014) Shading results in depletion of the soil seed bank. Nord J Bot 32:674-679

Baskin CC, Baskin JM (2014) Germination ecology of seeds in the persistent seed bank. In: Seeds: Ecology, Biogeography, and, Evolution of Dormancy and Germination, second edn. Academic Press, Amsterdam
Benvenuti S, Macchia M, Miele S (2001) Quantitative analysis of emergence of seedlings from buried weed seeds with increasing soil depth. Weed Sci 49: 528-535

Bisteau E, Mahy G (2005) Vegetation and seed bank in calcareous grasslands restored from a Pinus forest. Appl Veg Sci 8:167-174

Bossuyt B, Hermy M (2004) Seed bank assembly follows vegetation succession in dune slacks. J Veg Sci 15:449-456

Chao A, Chazdon RL, Colwell RK, Shen T (2006) Abundance-based similarity indices and their estimation when there are unseen species in samples. Biometrics 62:361-371

Cox RD, Allen EB (2008) Composition of soil seed banks in southern California coastal sage scrub and adjacent exotic grassland. Plant Ecol 198:37-46

DIGES (2012) Proposed construction of $100 \mathrm{MW}$ solar power plant on portion 6 and 7 of farm Bezuiidenhoutskraal 96 JR within Moretele Local Municipality of Bojanala Platinum District Municipality, North West Province. Draft scoping report.

Dodson EK, Peterson DW, Harrod RJ (2008) Understory vegetation response to thinning and burning restoration treatments in dry conifer forests of the eastern Cascades, USA. Forest Ecol Manage 255:3130-3140

Dolle M, Schmidt W (2009) The relationship between soil seed bank, aboveground vegetation and disturbance intensity on old-field successional permanent plots. Appl Veg Sci 12:415-428

Dreber N, Oldeland J, van Rooyen GMW (2011) Species, functional groups and community structure in seed banks of the arid Nama Karoo: Grazing impacts and implications for rangeland restoration. Agric Ecosyst Environ 141:399-409

Esmailzadeh O, Hosseini SM, Tabari M, Baskin CC, Asadi H (2011) Persistent soil seed banks and floristic diversity in Fagus orientalis forest communities in the Hyrcanian vegetation region of Iran. Flora 206:365-372

Espinar JL, Clemente L (2007) The impact vertic soil cracks on submerged microphyte diaspore bank depth distribution in Mediterranean temporary wetlands. Aquat Bot 87:325-328

Faist AM, Stone H, Tripp EA (2015) Impacts of mastication, soil seed bank responses to a forest thinning treatment in three Colorado (USA) conifer forest types. Forests 6:3060-3074

Farnsworth EJ, Plotkin AAB, Ellison AM (2012) The relative contributions of seed bank, seed rain, and understory vegetation dynamics to the reorganization of Tsuga canadensis forests after loss due to logging or simulated attack by Adelges tsugae. Can J Forest Res 42:2090-2105

Fey M (2010) Soils of South Africa. Cambridge University Press, Cambridge

Fourie S (2007) Composition of the soil seed bank in alien-invaded grassy fynbos, Potential for recovery after clearing. South Afr J Bot 74:445-453

Frank GS, Saunders MR, Jenkins MA (2018) Short-term vegetation responses to invasive shrub control techniques for Amur honeysuckle (Lonicera maackii [Rupr.] Herder). Forests 9:607. doi: https://doi.org/10.3390/f9100607 .

Gelviz-Gelvez SM, Sanchez-Montano LR, Lopez-Toledo L, Barragan F (2016) The Andean forest soil seed bank in two successional stages in northern Colombia. Bot Sci 94:1-15

Godefroid S, Phartyal SS, Koedam N (2006) Depth distribution and composition of seed banks under different tree layers in a managed temperate forest ecosystem. Acta Oecol 29:283-292

Gomaa NH (2012) Soil seed bank in different habitats of the Eastern Desert of Egypt. Saudi J Biol Sci. 19:211-220

Grossman D, Holden P (2007) Case studies on successful southern African NRM initiatives and their impacts on poverty and governance. International Resources Group, Washington, DC

Jonason D, Ibbe M, Milberg P, Tuner A, Westerberg L, Bergman K (2014) Vegetation in clear-cuts depends on previous land use: a century-old grassland legacy. Ecol Evol 4:4287-4295

Korb JE, Springer JD, Powers SR, Moore MM (2005) Soil seed banks in Pinus ponderosa forests in Arizona, Clues to site history and restoration potential. Appl Veg Sci 8:103-112

Lang NL (2006) The soil seed bank of an Oregon Montane Meadow: consequences of conifer encroachment and implications for restoration. Master's Thesis. University of Washington, Seattle, WA

Lemenih M, Teketay D (2006) Changes in soil seed bank composition and density following deforestation and subsequent cultivation of a tropical dry Afromontane forest in Ethiopia. Trop Ecol 47:1-12

Maclean JE, Michell RJ, Burslem DFRP, Genney D, Hall J, Pakeman RJ (2018) Invasion by Rhododendron ponticum depletes the native seed bank with long-term impacts after its removal. Biol Invasions 20:375-384 
Magurran AE (2004) Measuring biological diversity. Blackwell Science, Oxford Mbaluka KJ (2015) Ecological factors influencing distribution patterns of three Aristida species and their associated species in Kifuko ranch, Laikipia county, Kenya. Master's Thesis. Kenyatta University, Kenya

Miao R, Song Y, Sun Z, Guo M, Zhou Z, Liu Y (2016) Soil seed bank and plant community development in passive restoration of degraded sandy grasslands. Sustainability 8:581. https://doi.org/10.3390/su8060581

Mndela M, Madakadze IC, Nherera-Chokuda F, Dube S (2019) Dynamics of the soil seed bank over the short-term after bush clearing in a semi-arid shrubland in Springbokvlakte thornveld of South Africa. South Afr J Bot 125 298-309

Moerane R (2013) The impact of training using a structured primary animal health care model on the skills of rural small-scale farmers. Master's thesis. University of Pretoria, Pretoria, South Africa

Mucina L, Rutherfored MC, Palmer AR, Milton SJ, Scott L, Lloyd JW, van der Merve B, Hoare DB, Bezuidenhout H, Vlok JHJ, Euston-Brown DIG, Powrie LW, Dold AP (2006) Nama-karoo Biome. Strelitzia 19. South African Biodiversity Institute, Pretoria, South Africa.

Potgieter MJ, Mashatole MM, Jordaan JJ (2017) Long-term vegetation changes in the Pietersburg Plateau Bushveld of the Limpopo Province, South Africa: a new floristic assessment of the Turfloop Nature Reserve. Insights Forest Res 1:57-66

Price JN, Wright BR, Gross CL, Whalley WRDB (2010) Comparison of seedling emergence and seed extraction techniques for estimating the composition of soil seed banks. Methods Ecol Evol 1:151-157

Sakai A, Sato S, Sakai T, Kuramoto S, Tabuchi R (2005) A soil seed bank in a mature conifer plantation and establishment of seedlings after clear-cutting in southwest Japan. J Forest Res 10:295-304

SAS Institute (2009) Users guide, Statistics. SAS Institute Inc., Cary, NC

Schelling LR, McCarthy BC (2007) Effects of prescribed fire and thinning on the spatial heterogeneity of the seed bank in a mixed Oak forest. Nat Areas J 27: 320-331

Siebert F, Drebber N (2019) Forb ecology research in dry African savannas: knowledge, gaps and future perspectives. Ecol Evol 9:7875-7891

Smit GN (2005) Tree thinning as an option to increase herbaceous yield of an encroached semi-arid savanna in South Africa. BMC Ecol 5:4. https://doi.org/ 10.1186/1472-6785-5-4

Smith GF, Crouch NR, Figuereido E (2017) Field guide to succulents in southern Africa. Struik Nature, Cape Town, South Africa, pp 427-429

Stafford W, Birch C, Etter H, Blanchard R, Mudavanhu S, Angelstam P, Blignaut J, Ferreita L, Marais C (2016) The economics of landscape restoration: benefits of controlling bush encroachment and invasive plant species in South Africa and Namibia. Ecosys Serv 27:193-202

Tainton NM (1999) Veld management in South Africa. University of Natal Press, Pietermaritzburg

Tedder MJ, Kirkman KP, Morris CD, Trollope WSW, Bonyongo MC (2012) The influence of Pechuel-Loeschea leubnitziae (wild sage) on grass sward and soil seed bank composition. Afr J Range Forage Sci 29:101-107

Tessema KZ, de Boer WF, Prins HHT (2016) Changes in grass plant populations and temporal soil seed bank dynamics in a semi-arid African savanna: implications for restoration. J Environ Manage 182:166-175

Tiebel K, Huth F, Wagner S (2018) Soil seed banks of pioneer tree species in European temperate forests: a review. iForest 11: 48-57.

Van der Walt R (2009) Wildflowers of the Limpopo valley including Mapungubwe National Park. Musina, Business print. pp 11-335.

Van Oudtshoorn F (1999) Guide to grasses of southern Africa. Briza Publications, Pretoria

Veenendaal EM, Ernst WHO, Modise GS (1996) Effect of seasonal rainfall pattern on seedling emergence and establishment of grasses in a savanna in southeastern Botswana. J arid Environ 32:305-317

Vieira MDS, Bonilha CL, Boldrini II, Overbeck GE (2015) The seed bank of subtropical grasslands with contrasting land-use history in southern Brazil. Acta Bot Bras 29:543-552

\section{Publisher's Note}

Springer Nature remains neutral with regard to jurisdictional claims in published maps and institutional affiliations.

\section{Submit your manuscript to a SpringerOpen ${ }^{\circ}$ journal and benefit from:}

- Convenient online submission

- Rigorous peer review

- Open access: articles freely available online

- High visibility within the field

- Retaining the copyright to your article

Submit your next manuscript at $\boldsymbol{\nabla}$ springeropen.com 